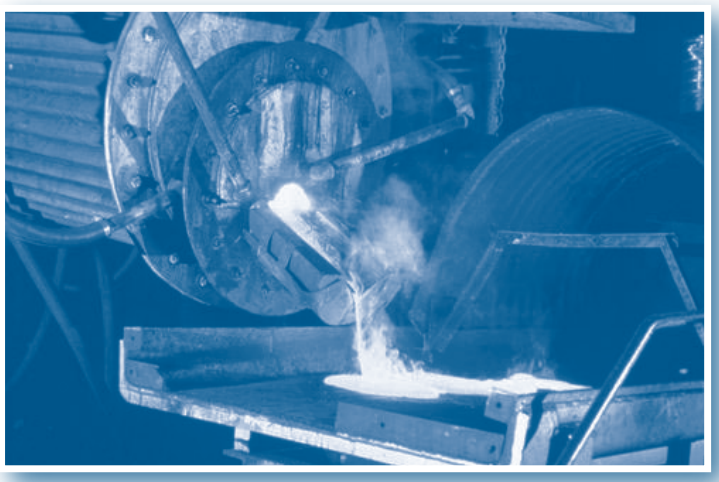

Companies recognize the value of natural gas as a versatile, clean-burning fuel, but because prices are highly variable, many are looking for more efficient process heating methods.

\section{Don't let natural gas prices burn your company!}

Discover how to conserve natural gas and keep your energy bills to a minimum.

\section{DOE is committed to helping} industries lower their energy bills. The Industrial Technologies Program offers your company

- Training

- Software tools

- No-cost assessments

- Tip sheets, guidebooks, and more

These tools and resources can help you cut costs, save energy, and reduce waste today.

\section{Real savings could be just one step away...}

A Rohm and Haas chemical plant used DOE's PHAST assessment tool to identify potential savings; the plant then reduced its energy costs by $\$ 2$ million per year by replacing an older gas-fired furnace and preheater with efficient new equipment. Associated process improvements save another $\$ 5$ million, so the payback was only about $2 \frac{1}{2} 2$ years.

The Deer Park, Texas, plant produces about 5 billion pounds of chemical products annually and reclaims 3,600 tons of sulfuric acid per day by decomposing sulfuric acid residue.

\section{A Strong Energy Portfolio for a Strong America}

Energy efficiency and clean, renewable energy will mean a stronger economy, a cleaner environment, and greater energy independence for America. Working with a wide array of state, community, industry, and university partners, the U.S. Department of Energy's Office of Energy Efficiency and Renewable Energy invests in a diverse portfolio of energy technologies.

For Additional Information, Please Contact:

Energy Efficiency and Renewable Energy Information Center 1-877-EERE-INF (1-877-337-3463)

www.eere.energy.gov/industry/

Industrial Technologies Program

Energy Efficiency and Renewable Energy

U.S. Department of Energy

Washington, DC 20585-0121

\title{
Reduce Natural Gas Use in Your Industrial Process Heating Systems
}




\section{Ten Tips for Saving Natural Gas in Process Heating Systems}

\section{Think saving energy will require costly new equipment?}

\section{Think again.}

Cutting your natural gas bill can be as simple as adjusting a dial.

Get started by taking some simple, lowcost steps to savings and by encouraging employees to become actively involved.

You might also want to consider additional measures, such as requesting a Save Energy Now plant energy assessment of your process heating system through the Department of Energy's (DOE) Industrial Technologies Program.

\section{Equipment}

These tips could reduce your energy use by $2 \%$ to $5 \%$ :

- Make sure that furnace and oven walls and doors are insulated well enough to minimize heat losses and to help keep temperatures low on the outside surfaces of equipment.

- Reduce or eliminate water-cooled parts inside a furnace or oven, wherever you can; if cooled parts are necessary, make sure that those parts are well insulated to reduce heat transfer to them.

- Control make-up air for ovens and other heating equipment to keep it at the minimum value required to meet process and equipment safety requirements.

- Reduce or eliminate openings in furnace walls and doors to minimize heat losses and to prevent air from leaking into furnaces and ovens.

- Use pressure controls with fired or electrically heated furnaces and ovens to minimize air leaks into the furnace or hot gas leaks from equipment.

- Use automatic controls to regulate the air-fuel ratio and minimize excess air for burners at all firing rates, while ensuring that there are no excess unburned hydrocarbons such as carbon monoxide, hydrogen, methane, or soot in exhaust gases.

\section{Maintenance}

This tip could reduce your energy use by $2 \%$ to $5 \%$ :

- Clean heat transfer surfaces frequently to maintain high heat transfer efficiency in heat exchangers and other systems that use electrical heating elements, coils, radiant tubes, and so on.

\section{Operations}

These tips could reduce your energy use by $10 \%$ to $25 \%$ :

- Consider recovering heat from exhaust or flue gases for use in heating air, water, and oils or in preheating charge material going into a furnace or oven.

- Consider preheating combustion air by using a recuperator or a regenerator to recover the heat of exhaust gases from a furnace or oven.

- Use efficient operating practices, such as operating heating equipment at close to full load or design load capacity, avoiding delays between cycles, and minimizing the weight of load supports, such as fixtures, trays, and baskets.

Visit these sites to find more ways to reduce natural gas bills and improve energy efficiency:

DOE Industrial Technologies Program www.eere.energy.gov/industry/

ITP Process Heating Tip Sheets www.eere.energy.gov/industry/bestpractices/ tip_sheets_process_heating.html

ITP Process Heating Information www.eere.energy.gov/industry/bestpractices/ techpubs_process_heating.html

Save Energy Now

www.eere.energy.gov/industry/saveenergynow

Industrial Heating Equipment Association www.ihea.org 